\title{
PEMETAAN AKTIFITAS KONSUMEN TOKO MENGGUNAKAN METODE BACKGROUND SUBTRACTION
}

\author{
I Made Edy Listartha ${ }^{1}{ }^{*}$, Gede Indrawan ${ }^{2}$, Kadek Yota Ernanda Aryanto ${ }^{3}$ \\ 1 Universitas Pendidikan Ganesha \\ 2 Universitas Pendidikan Ganesha \\ ${ }^{3}$ Universitas Pendidikan Ganesha
}

\begin{abstract}
Abstrak
This study aims to heat mapping the consumer's movement using background subtraction techniques. The mapping is built using the coordinate information obtained from the consumer location that detected from the video where the separation of the consumer object and the background is done by background subtraction technique. Tests were performed on eleven video of consumer data activity that have different activity characteristics that were created using Microsoft PowerPoint application. Simulated activities include walking straight, staying, walking back to the path that had been passed, pacing, disturbance from another object, the influence of color, the consumer walks meet and coincide with other consumers. From the test of video discovery is obtained accuracy of $96.07 \%$ for the detection process of consumer movement, where the lack of detection process occurs due to the absence of techniques used to perform the introduction of characteristics of consumer objects. The mapping process is very much in line with the number of coordinates generated in the motion detection process, but the inaccurate detection of movement in the entrance and exit areas makes the coordinates high. By filtering with Region of Interes (ROI) in the survey area, creating disturbances in the area of doors and areas with objects that produce movements other than consumers can be eliminated.
\end{abstract}

\author{
Keywords: \\ object tracking, object \\ heat mapping
}

\section{PENDAHULUAN}

Pembangunan pemetaan konsumen di dalam toko secara visual dapat mempresentasikan informasi mengenai prilaku pola berkeliling konsumen dan melihat efektivitas dari penataan ruang di dalam toko (Tickto, 2015). Informasi visual ini dipresentasikan dengan menggunakan variasi warna yang berbeda-beda, yang dimana setiap warna akan memiliki arti yang berbeda atau menggambarkan adanya nilai yang berbeda untuk setiap data yang berbeda dalam hasil pemetaannya (Deu-Pons, Schroeder dan Lopez-Bigas, 2014).

Dalam membangun pemetaan ini, kita dapat memanfaatkan sumber data dari kamera pengawas yang umumnya terpasang pada toko. Nantinya, data mengenai pergerakan setiap konsumen akan diambil pola berkelilingnya dan kemudian dibangun pemetaannya. Namun proses pengambilan informasi pergerakan konsumen ini tidaklah mudah (Breimer, Cotler dan Yoder, 2012). Karena sumber data adalah data video, diperlukan adanya metode yang dapat memisahkan setiap elemen pada setiap gambar dalam video dan hanya mengambil elemen (gambar konsumen) yang di perlukan.

Pemisahan ini nantinya akan memanfaatkan metode Background Subtraction karena merupakan metode yang disara tepat digunakan untuk mendeteksi objek bergerak pada video dari kamera statis (stationary camera) (Solichin dan Harjoko, 2013). Proses deteksi objek bergerak dengan metode background subtraction didasarkan pada perbedaan antara background referensi dengan frame (Irianto, Ariyanto dan P, 2009). Noise yang ditimbulkan dalam proses pemisahan ini akan di saring dengan proses threshold citra dan operasi morfologi untuk memperbaiki citra yang terganggu dari proses pemisahan tersebut.

Dalam pengujiannya nanti, penulis akan membuat beberapa video simulasi lingkungan toko dengan menggunakan aplikasi Microsoft PowerPoint yang dimana aplikasi ini dapat digunakan untuk membangun animasi sederhana (Microsoft, 2017). 
Dalam penelitian ini yang menjadi rumusan masalah adalah tentang bagaimana implementasi teknik Backgroung Subtraction dapat mengenali objek yang bergerak dan mengikutinya. Kemudian tentang bagaimana proses pembentukan heatmap lalulintas pengunjung toko berdasarkan pelacakan yang dilakukan. Berdasarkan rumusan masalah di atas, adapun tujuan yang ingin dicapai dalam penelitian yaitu memanfaatkan teknik Background Subtraction dalam mengenali objek yang bergerak dan mengikutinya. Kemudian membuat heatmap dalam toko untuk mendapatkan lokasi lalulintas pengunjung.

Batasan masalah yang dibahas dalam penelitian ini diantaranya adalah metode yang digunakan dalam melacak pergerakan objek menggunakan Background Subtraction dan Operasi Morfologi. Kemudian pengenalan objek hanya untuk mengetahui lokasi dan pergerakannya, tidak dilakukan identifikasi terhadap objek tersebut maupun aktivitas lainnya. Selain itu kamera diletakkan pada lingkungan statis.

\section{METODE PENELITIAN}

Penelitian dan pengembangan yang dilakukan adalah untuk menghasilkan produk algoritma analisa pola berkeliling pembeli di dalam sebuah toko dan mendapatkan heatmap (pemetaan) dari setiap area. Penelitian ini akan dibagi menjadi beberapa tahapan, setiap tahapan akan membantu menentukan hasil yang sesuai dengan tujuan penelitian. Tahapan yang digunakan digambarkan dengan flowcart sesuai dengan gambar berikut:

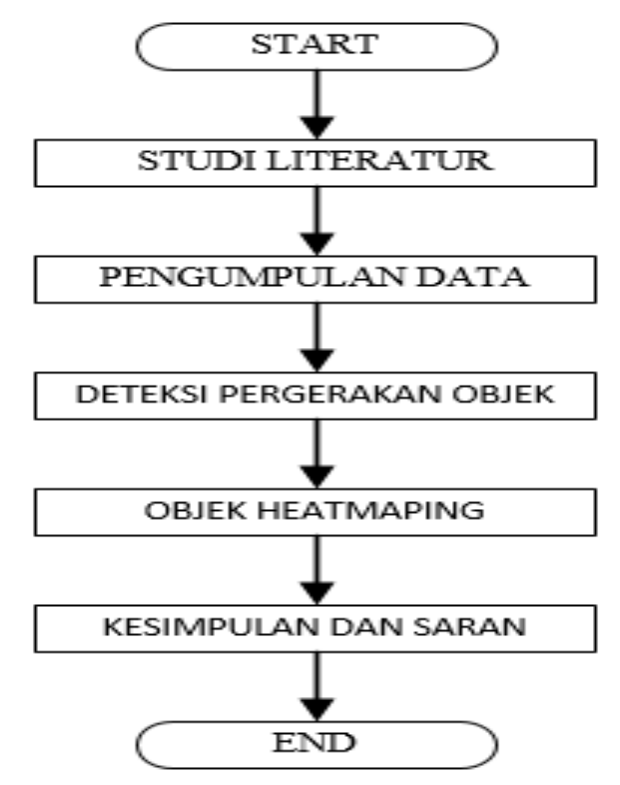

Gambar 1. Tahapan Penelitian.

Studi literatur dilakukan untuk mengkaji penelitian-penelitian yang pernah dilakukan yang berkaitan dengan Background Subtraction, Operasi Morfologi dan teknik-teknik yang berkaitan dalam mendapatkan informasi mengenai lokasi objek pada gambar dan membaca pola pergerakan pada gambar. Untuk karakteristik data yang dibuat adalah berjalan lurus, berdiam pada suatu lokasi saat berkeliling, berjalan kembali ke jalur yang pernah di lewati, mondar-mandir pada rak produk tertentu seperti mencari barang, adanya objek lain yang menghasilkan gerakan seperti kipas angin dan layar tampilan produk, konsumen menggunakan warna pakaian yang sama dengan latar warna toko, konsumen berjalan berpapasan dan berbarengan dengan konsumen lain.

Proses pendeteksian objek bergerak memerlukan beberapa proses hingga mendapatkan hasil yang diinginkan. Untuk pendeteksian ini, akan dilakukan proses-proses sebagai berikut: 


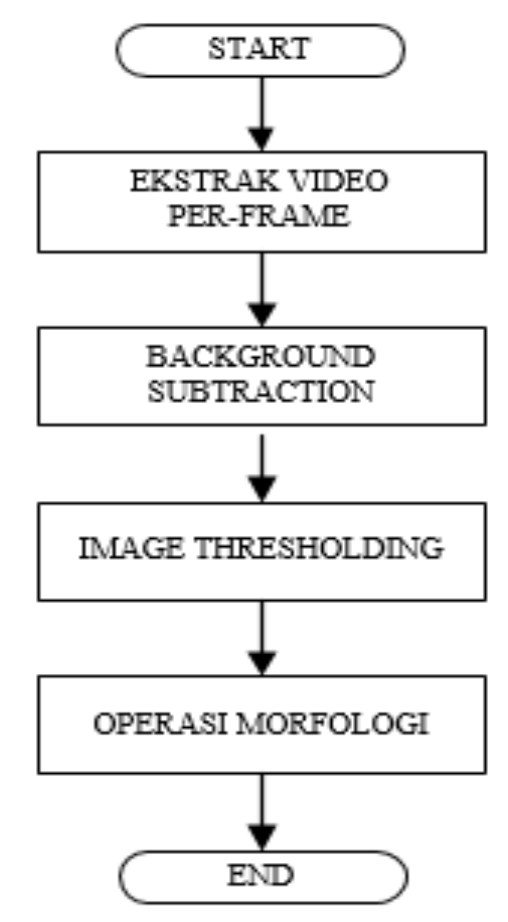

Gambar 2. Tahapan Deteksi Objek Bergerak.

Proses ekstraksi ini dilakukan untuk memperoleh gambar-gambar (frame) dari data video sesuai dengan FPS (frame per-second). Setiap gambar ini nantinya akan di dibandingkan pada proses background subtraction untuk mendapatkan objek yang bergerak. Pada bahasa pemrograman Python yang terintegrasi dengan OpenCV 3.2, fungsi ini dilakukan pada perintah cv2.read(). Hal ini dilakukan karena algoritma proses background subtraction memerlukan masukan gambar per gambar.

Hasil pemisahan ini akan menghasilkan gambar hitam dan putih, dimana putih mempresentasikan objek yang bergerak. Di dalam proses ini gambar yang berwarna akan di ubah menjadi gambar keabuan dengan tujuan untuk merubahnya menjadi citra biner. Gambar frame awal yang belum berisi objek yang bergerak akan dibersihkan dari noise untuk menghasilkan background yang stabil dan peka terhadap perubahan foreground. Pada bahasa pemrograman Python yang terintegrasi dengan OpenCV 3.2, fungsi ini dilakukan dengan membuat objek dari fungsi cv2.createBackgroundSubtractorMOG20 kemudian menggunakan fungsi bs.apply(frame) pada frame video yang akan dibandingkan. Tidak ada parameter khusus yang ditambahkan dalam fungsi background subtraction ini, parameter mengikuti konfigurasi default.

Hasil pemisahan dengan teknik background subtraction menghasilkan citra yang terdiri dari warna abu dan warna putih. Sehingga image thresholding ini digunakan untuk proses mengubah citra berderajat keabuan menjadi citra biner atau hitam putih sehingga dapat diketahui daerah mana yang termasuk obyek dan background dari citra secara jelas. Pada bahasa pemrograman Python yang terintegrasi dengan OpenCV 3.2, fungsi ini dilakukan dengan menggunakan fungsi yang terdapat pada objek cv2 dengan perintah cv2.threshold(frame, $x, y, c v 2$.THRESH_BINARY).

Untuk memaksimalkan hasil bentuk objek yang didapatkan, hasil yang berisi noise dan objek yang terpotong akan diperbaiki sebelum dilakukan proses deteksi lokasi objek. Operasi morfologi yang akan digunakan adalah operasi Open untuk menghilangkan noise dan operasi Close untuk mengisi lubanglubang kecil pada objek yang kemungkinan timbul dalam proses sebelumnya.

Proses heatmaping atau pemetaan lokasi objek ini akan melalui proses pelacakan posisi setiap objek pada setiap frame. Data lokasi setiap objek tersebut akan direkam dan digabungkan dari setiap frame. Berikut alur proses pembentukan heatmap berdasarkan proses sebelumnya dan riwayat lokasi setiap objek: 


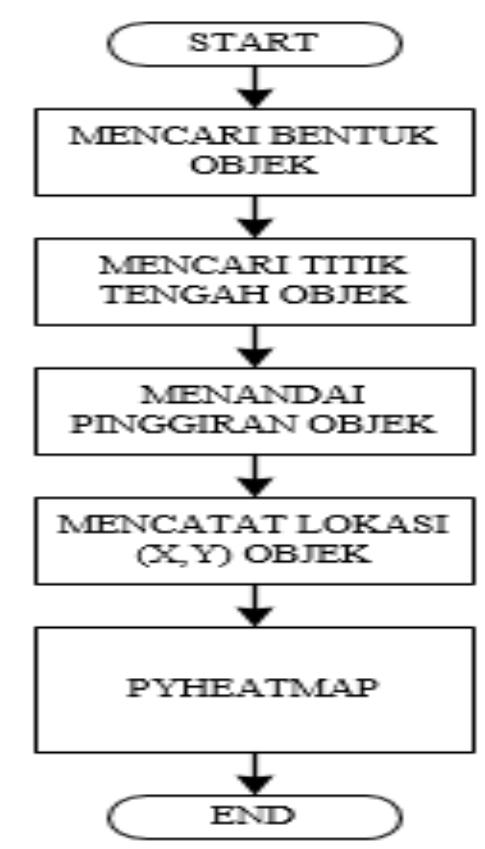

Gambar 3. Tahapan Pemetaan Riwayat Objek.

Operasi morfologi yang telah dilakukan akan menyisakan citra yang bergerak yang telah terpisah dari background, sebelum bisa masuk ke tahap selanjutnya objek harus dideteksi bentuknya untuk mendapatkan ukuran dari objek dan jumlah objek yang terdeteksi dalam citra. Fungsi yang digunakan dalam operasi ini adalah cv2. findContours(). Kontur adalah garis khayal yang menghubungkan titik-titik yang mempunyai ketinggian yang sama. Kontur ini dapat memberikan informasi relief, baik secara relatif, maupun secara absolut.

Objek-objek yang terdeteksi tersebut kemudian dicari titik tengahnya dalam koordinat x,y pada citra. Untuk memudahkan membedakan objek satu dengan yang lain, maka setiap objek akan di gambar garis tepiannya dengan garis sehingga lebih memudahkan pengenalan. Setelah semua proses diatas dilakukan kemudian dilakukan pencatatan lokasi koordinat dalam sebuah file yang akan digunakan oleh library PyHeatMap untuk diproses menjadi informasi visual.

Data yang dibuat dengan PowerPoint 2916 dan digunakan dalam pengujian proses pelacakan dan pemetaan ini terdiri dari beberapa file video. Karakteristik dari setiap video tersebut disesuaikan dengan nama file dan ditampilkan pada Tabel 1:

Tabel 1. Karakteristik Data Video

\begin{tabular}{llrrr} 
No. & Nama Video & Resolusi & FPS & Waktu \\
\hline 1 & Lurus.mp4 & $852 \times 480$ & 30 & 7 detik \\
2 & Berdiam.mp4 & $852 \times 480$ & 30 & 12 detik \\
3 & Bersilang.mp4 & $852 \times 480$ & 30 & 5 detik \\
4 & Berulang.mp4 & $852 \times 480$ & 30 & 7 detik \\
5 & Kipas.mp4 & $852 \times 480$ & 30 & 8 detik \\
6 & Kipas2.mp4 & $852 \times 480$ & 30 & 8 detik \\
7 & Layar.mp4 & $852 \times 480$ & 30 & 10 detik \\
8 & Warna.mp4 & $852 \times 480$ & 30 & 7 detik \\
9 & Berpapasan.mp4 & $852 \times 480$ & 30 & 5 detik
\end{tabular}




$\begin{array}{lllll}10 & \text { Berbarengan.mp4 } & 852 \times 480 & 30 & 5 \text { detik } \\ 11 & \text { Menyebar.mp4 } & 852 \times 480 & 30 & 8 \text { detik }\end{array}$

Untuk mendapatkan nilai dari akurasi di setiap video, maka akan dibangun sebuah XY blok pada dasar video kemudian dibuatkan jalur sesuai arah yang diinginkan. Hasil video ini kemudian di terapkan pada aplikasi yang di bangun dan dibandingkan antara koordinat hasil dan koordinat sketsanya. Ukuran total dari lingkungan yang akan di bangun adalah lebar 852 pixel dan tinggi 480 pixel.

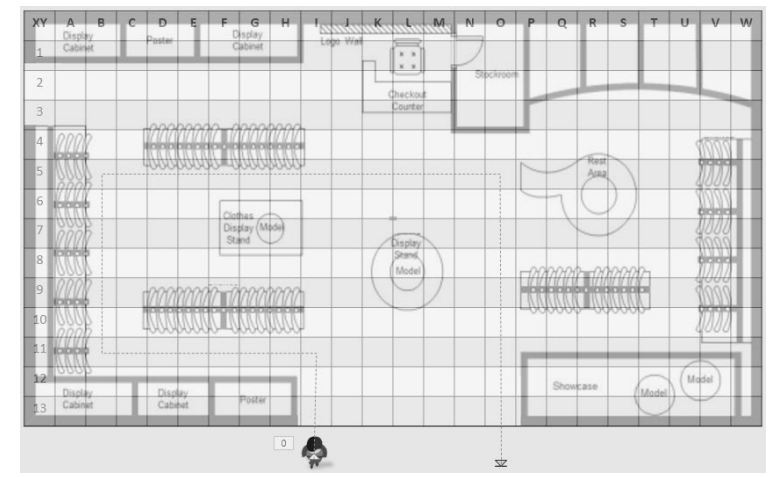

Gambar 4. XY Blok dan Sketsa

Untuk lebar akan di bagi menjadi 24 blok sehingga di dapatkan ukuran 35,5 pixel dan tinggi dibagi menjadi 14 blok sehingga di dapatkan ukuran 34,3 pixel. Untuk objek konsumen akan disesuaikan dengan ukuran per blok untuk memberikan nilai akurasi yang lebih baik, karena bagian mana pun dari konsumen yang terdeteksi akan tetap di dalam ukuran blok.

Nilai akurasinya sendiri nanti akan dihitung berdasarkan jumlah dari blok yang terdeteksi benar kemudian di bagi dengan jumlah blok yang dilewati dalam setiap video, rumusnya sebagai berikut:

$$
\text { Akurasi Deteksi }=\frac{\text { Jumlah Blok Benar }}{\text { Jumlah Blok Keseluruhan }} \times 100 \%
$$

Kemudian untuk mendapatkan nilai akurasi rata-rata dari setiap video yang di ujikan, dilakukan penjumlahan nilai persentase yang benar di bagi dengan jumlah persentase keseluruhan, rumusnya sebagai berikut:

$$
\text { Akurasi Deteksi Global }=\frac{\text { Total Akurasi Deteksi Semua Video }}{\text { Total Nilai Maksimum Persentase }} \times 100 \%
$$

\section{ANALISIS DAN PEMBAHASAN}

Dalam mendapatkan hasil penelitian ini, dibangun aplikasi berdasarkan landasan teori untuk menganalisis video simulasi lingkungan toko. Kemudian hasil tersebut dibandingkan untuk mendapatkan nilai akurasi dari deteksi dan pemetaan. Hal tersebut disajikan dalam Tabel 2 berikut ini:

Tabel 2. Akurasi Hasil Deteksi

\begin{tabular}{cccc}
\hline \multirow{2}{*}{ Nama Video } & \multicolumn{3}{c}{ Resolusi } \\
& Blok Benar & $\begin{array}{c}\text { Total } \\
\text { Blok }\end{array}$ & $\%$ \\
\hline Lurus.mp4 & 37 & 37 & $100 \%$ \\
Berdiam.mp4 & 22 & 22 & $100 \%$ \\
Bersilang.mp4 & 24 & 24 & $100 \%$ \\
Berulang.mp4 & 30 & 30 & $100 \%$ \\
\hline
\end{tabular}




\begin{tabular}{cccc}
\hline Kipas.mp4 & 22 & 22 & $100 \%$ \\
Kipas2.mp4 & 22 & 29 & $75,86 \%$ \\
Layar.mp4 & 20 & 24 & $83,33 \%$ \\
Warna.mp4 & 20 & 20 & $100 \%$ \\
Berpapasan.mp4 & 39 & 39 & $100 \%$ \\
Berbarengan.mp4 & 41 & 42 & $97,61 \%$ \\
Menyebar.mp4 & 119 & 119 & $100 \%$ \\
Nilai Rata-Rata Akurasi & & & $\mathbf{9 6 , 0 7 \%}$ \\
\hline
\end{tabular}

Dari hasil analisa dilihat pula adanya perbedaan hasil dari rencana sketsa video yang di buat. Dengan menetapkan waktu yang sama, objek konsumen yang bergerak ke arah sumbu X selalu memiliki hasil koordinat yang lebih sedikit di bandingkan dengan konsumen yang bergerak ke arah sumbu Y.

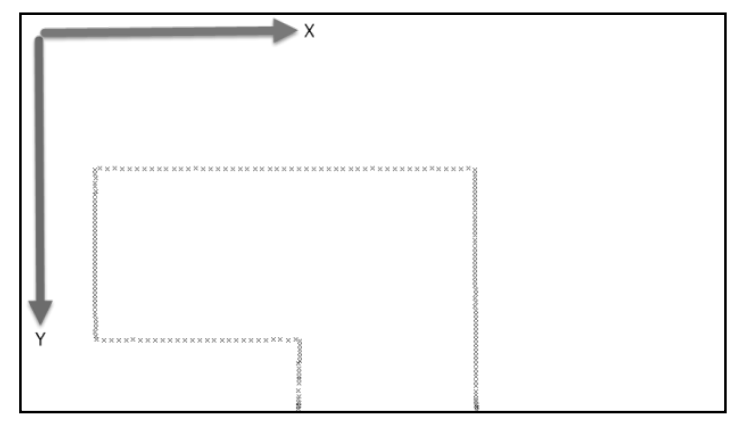

Gambar 5. Perbedaan Kepadatan

Proses pemetaan menghasilkan data yang sesuai dengan nilai pada setiap area blok, namun nilai tinggi di temukan pada blok tempat objek muncul dan keluar. Hal ini disebabkan saat objek konsumen muncul mulai dari bagian kepala sampai kaki terdeteksi pada tempat yang sama sehingga blok tersebut menghasilkan banyak nilai koordinat.

Dalam setiap video yang di bangun, untuk pintu keluar dan masuk berada di sisi kiri pada blok A2 dan A3, beserta sisi bawah pada blok I13, J13, K13, L13, M13, N13 dan 013. Dengan mengecualikan daerah ini pada pembentukan heatmap, maka hasil pemetaan pada area ROI menjadi lebih baik.

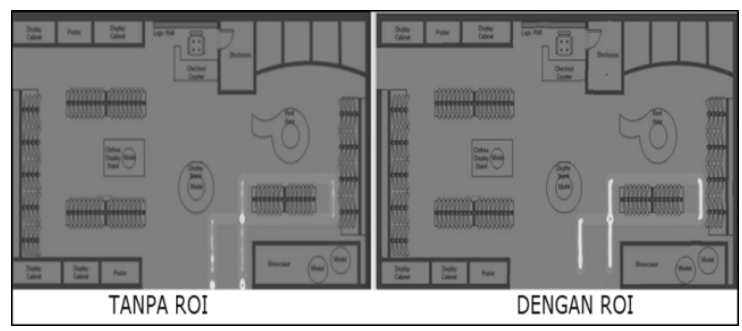

Gambar 6. Perbandingan Hasil ROI

Dengan menggunakan filter ini, dengan mudah dapat ditentukan daerah mana yang ingin menjadi fokus dalam pembentukan heatmap, dan dengan hanya mengubah atau menghapus koordinat yang tidak diinginkan pada text file yang di bentuk oleh proses deteksi objek bergerak.

\section{KESIMPULAN}

Dari proses penelitian ini didapatkan informasi bahwa teknik background subtraction dapat digunakan dalam proses pelacakan pergerakan objek pada data video dengan kamera statis dengan 
tingkat akurasi sebesar 96,07\%. Penerapan operasi morfologi juga mampu mendeteksi objek orang yang diharapkan lebih baik dengan menghilangkan gangguan visual yang ada pada video.

Teknik yang diterapkan pada penelitian ini tidak mampu mendeteksi dengan baik saat objek konsumen yang menjadi fokus pelacakan melakukan aktivitas yang berdiam, berpapasan dengan objek konsumen lain maupun berjalan berbarengan yang membuat secara visual objek konsumen terlihat menjadi satu. Kesalahan deteksi yang di hasilkan dalam penelitian ini lebih banyak disebabkan karena tidak adanya kemampuan teknik yang digunakan dalam melakukan pengenalan karakteristik dari objek konsumen.

Proses pemetaan berjalan baik pada proses ini, sehingga tidak ditemukan kendala yang berarti. Karena nilai dari yang dipetakan tergantung dari akurasi nilai koordinat yang didapatkan oleh proses pelacakan. Dalam mempermudah analisis terhadap informasi yang di hasilkan, dapat menerapkan Region of Interes (ROI) untuk memfilter hasil dari informasi yang di dapatkan.

Dengan menggunakan teknik ROI, kita dapat dengan mudah fokus dengan daerah tertentu untuk dilakukan analisa. ROI juga dapat digunakan untuk menghilangkan daerah yang memiliki gangguan hasil deteksi dengan mengecualikannya dari hasil pemetaan. Pengembangan Penelitian Berikutnya Untuk meningkatkan akurasi pelacakan dan pemetaan dari penelitian ini, beberapa hal yang dapat di perbaiki maupun dikembangkan yaitu: a) Untuk proses deteksi objek bergerak bisa menambahkan operasi pengenalan karakteristik objek untuk mengatasi deteksi yang hilang saat objek bergerak diam. Dengan melakukan pengenalan terhadap setiap objek maka jika objek berbeda bertumpuk maka akan tetap dikenal sebagai objek yang berbeda dan objek dengan posisi jauh pun dapat dikenali. Pengenalan ini juga dapat membantu mencari lokasi koordinat berdasarkan lokasi kaki maupun tangan objek orang, b) Pengaturan nilai morfologi secara dinamis menggunakan algoritma tertentu untuk menyesuaikannya dengan ukuran data video dan ukuran Noise yang secara umum terdeteksi.

Melakukan pengenalan terhadap awal objek bergerak beserta akhirannya dengan menerapkan pencatatan waktu di setiap koordinat, sehingga nantinya dapat mengetahui arah pergerakan awal dan akhir dari setiap objek yang ada di dalam video.

\section{DAFTAR PUSTAKA}

Adrian Rosebrock (2017) Imutils. Tersedia pada: http://github.com/jrosebr/imutil.

Bradley, D. dan Roth, G. (2007) “Adaptive Thresholding using the Integral Image,” Journal of Graphics Tools, 12(2), hal. 13-21. doi: 10.1080/2151237X.2007.10129236.

Breimer, E., Cotler, J. dan Yoder, R. (2012) “Video vs. text for lab instruction and concept learning,” Journal of Computing Sciences in Colleges, 27, hal. 42-48. Tersedia pada: http://dl.acm.org/citation.cfm?id=2184462.

Deu-Pons, J., Schroeder, M. P. dan Lopez-Bigas, N. (2014) "JHeatmap: An interactive heatmap viewer for the web," Bioinformatics, 30(12), hal. 1757-1758. doi: 10.1093/bioinformatics/btu094.

Idris, I. (2012) NumPy Cookbook, NumPy Cookbook. doi: 10.1017/CB09781107415324.004.

Irianto, K. D., Ariyanto, G. dan P, D. A. (2009) "Motion Detection Using Opencv With Background Subtraction and Frame Differencing Technique," hal. 74-81.

JetBrains (2017) PyCharm. Tersedia pada: https://www.jetbrains.com/pycharm/.

Kurnia, M. R., Tjandrasa, H. dan Wijaya, Y. (2012) “Implementasi Segmentasi Pembuluh Darah Retina Pada Citra Fundus Mata Menggunakan Tekstur, Thresholding dan Operasi Morfologi,” Jurnal Teknik Pomits, 1(1), hal. 1-6.

Lutz, M. (2007) Learning Python, Icarus. doi: 10.1016/0019-1035(89)90077-8.

Microsoft (2017) PowerPoint Help Center. Tersedia pada: https://support.office.com/en-us/powerpoint.

Munir, R. (2004) “Pendeteksian Tepi (Edge Detection),” in Pengolahan Citra Digital dengan pendekatan algoritmik, hal. 121-140.

Oldj (2012) Python Heat Map Library, GitHub. Tersedia pada: https://github.com/oldj/pyheatmap. 
Solichin, A. dan Harjoko, A. (2013) "Metode Background Subtraction untuk Deteksi Obyek Pejalan Kaki pada Lingkungan Statis," Jurusan Ilmu Komputer dan Elektronika, Fakultas MIPA, Universitas Gajah Mada, Yogyakarta, hal. 1-6.

Sugiyono (2012) Statistika Untuk Penelitian, Penerbit Alfabeta. doi: 2011.

Tickto (2015) Heat map analytics and its impact on Retail, Tickto. Tersedia pada: https://retailstoreanalytics. $\quad$ wordpress.com/2015/05/20/heat-map-analytics-and-its-impact-onretail/ (Diakses: 18 Juni 2017).

Umam, K. dan Negara, B. S. (2016) “Deteksi Obyek Manusia Pada Basis Data Video Menggunakan Metode Background Subtraction Dan Operasi Morfologi," Jurnal CoreIT, 2(2), hal. 31-40.

Zelinsky, A. (2009) "Learning OpenCV???Computer Vision with the OpenCV Library," IEEE Robotics and Automation Magazine, hal. 100. doi: 10.1109/MRA.2009.933612. 